\title{
THE HISTORY OF THE SUMMER SURVEY OF THE Hungarian Royal Public Higher Architectural SCHOOL - IN THE MIRROR OF COLLECTION RESOURCES
}

\author{
Gergely Kovács \\ Collection's reference-art historian, Hungarian Academy of Arts, Hungarian Museum \\ of Architecture and Documentation Center of Cultural Heritage Management \\ kovacs.gergely.karoly@mma-mem.hu
}

\begin{abstract}
After studying in Budapest and Wien, Ernö Foerk first became an assistant to Imre Steindl at the Royal Joseph's Polytechnic and later he started teaching at the Hungarian Royal Public Higher Architectural Industrial School. The practice of holiday surveys which is largely based on the experience gained in Wiener Bauhütte in Wien can be captured as a link between these two activities. Foerk's full teaching activity was followed by the holiday paths he had with his students. These of course were also inextricably linked with the activities of the cultural heritage management at this time; the drawings made at that time were included in the National Committee of Monuments. Processing of the group in question may raise new issues of the history of architecture and scientific history possibly for wellknown monuments, sometimes for one person, as well as for a comprehensive look at Foerk's model which has been previously sporadically examined.
\end{abstract}

Keywords: holiday surveys, Hungarian Royal Public Higher Architectural Industrial School, Hungarian Royal Joseph's Polytechnic, National Committee of Monuments, Wiener Bauhütte

\section{INTRODUCTION}

This paper is based on the recent processing of the drawing material which made in the course of the Hungarian Royal Public Higher Architectural Industrial School (hereinafter: „industrial school”) holiday surveys, currently kept by the Center of Cultural Heritage Management's storage plan. The collection unit in question includes the students' surveys - led by Imre Steindl from 1874 to 1897 - plans of the Royal Joseph's Polytechnic besides the institution under investigation. This work included the accumulation and cataloging of plans, the matching of manuscripts fixed on the spot and clear drawings, as well as researching other sources of public collection - primarily from the National Committee of Monuments' archive and the Hungarian Museum of Architecture - related to this topic.

Previously László Pusztai, [1] András Hadik [2] and Attila Déry [3] had already delineated the scientific outlines of architectural issues inherent in holiday surveys. In the following, we will try to add suggestions based on so far unprocessed source data so far. It is to be noted as a working hypothesis that we presume an organic connection between the holiday surveys of the polytechnic and the industrial school. Therefore, we approach investigation of the latter through the former, to outline the science-historical image of the subject through each link and counterpoint. 


\section{FROM WIEN TO BUDAPEST - THE SCHMIDT TRADITIONS}

By the character of Ernö Foerk, the surveys of the industrial school point to the direction of the Emperor's Town. After finishing the Academy of Applied Arts in Budapest in 1888, in 1889 he became a scholarship student of Friedrich von Schmidt at the Academy of Fine Arts in Wien (Akademie der bildenden Künste), [4] where - in collaboration with others Imre Steindl, Frigyes Schulek and Ferenc Schulcz - organized a self-formation circle [5] named Wiener Bauhütte around the master in 1862 and which Foerk was also a member. [6] In essence the holiday surveys of the polytechnic began as the latter's domestic implementation in the circle of Steindl's students, who had been involved in this activity between organized frames since 1878, as the Association of Polytechnic's Architect Students. [7]

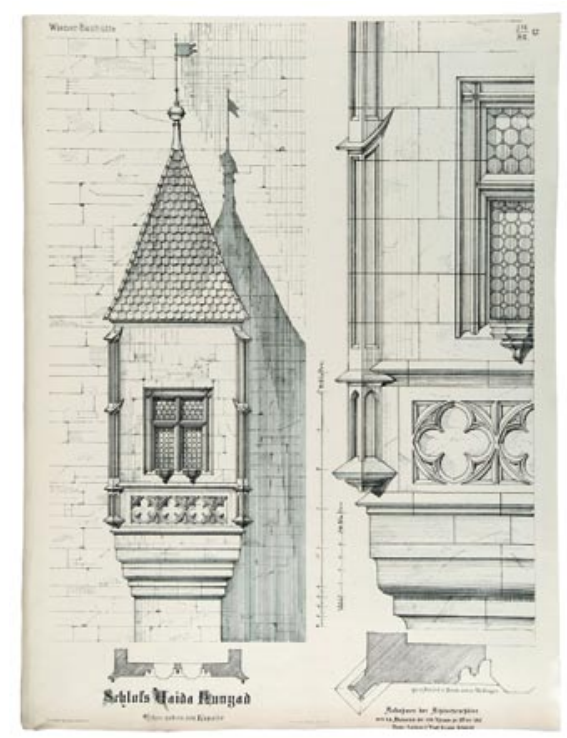

Picture 1. Vajdahunyad, castle. Closed balcony next to the chapel.

(Wiener Bauhütte, 1867. MMA, MÉM-MDK, Tervtár, ltsz. K 11720)

Foerk came to this agent when becoming the assistant of Steindl at the university in 1893, [8] and then in 1895-1896 he participated in the holiday surveys of Gyulafehérvár, Szászbogács and Prázsmár. Later, during the outsourcing organized by the industrial school, he used his experiences gained at the time. While in Prázsmár and Bogács he writes in his journal entry of 16 June 1916 that ,the recordings are the same as the 20-year-old recordings of the Polytechnic which I guided as an assistant. Only the recording of the fort is missing." [9]

Foerk continued the Steindl tradition as a teacher of the industrial school and the holiday surveys. It is no coincidence that in his commemorative speech at the twenty-fifth anniversary of the master's death, Foerk placed a particular emphasis on his teaching activities, especially for the ,survey paths”, in which his students ,have even more share in [...] the wealth of his experiences." [10] Tradition which is still in existence until the Wiener Bauhütte has never been worn out. One of the reasons for this is that Lajos Schodits, [11] who held the post of director of the institution between 1918 and 1933, [12] was a Steindl disciple, and in 1894 and 1896 [13] he also participated in the summer survey of the Polytechnic's students in Árvaváralja. [14] In other words, this practice was not unknown either. 


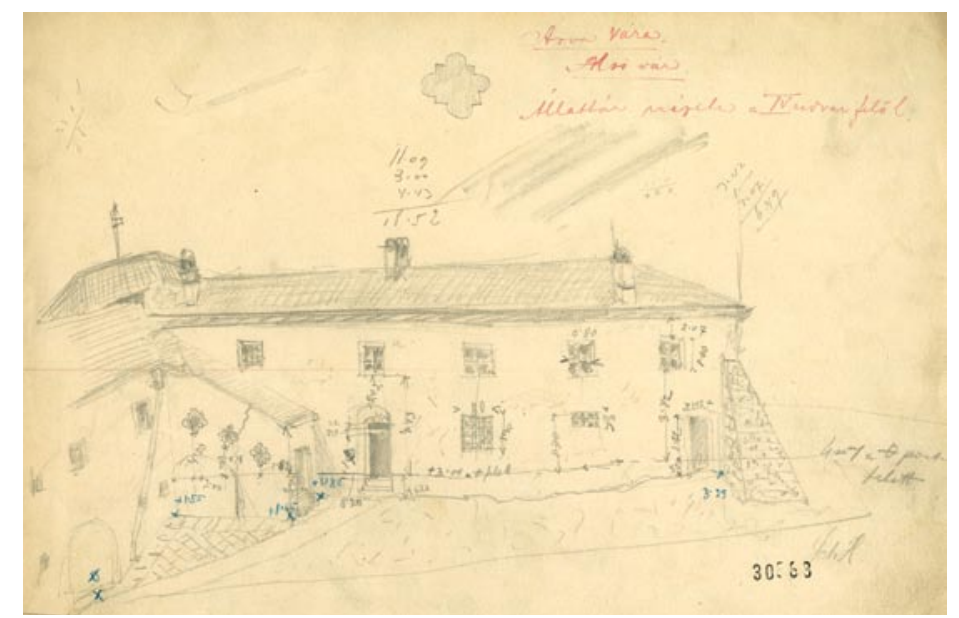

Picture 2. Lajos, Schodits: Árva, castle. The facade of lower castle.

(Joseph's Polytechnic, 1894. MMA, MÉM-MDK, Tervtár, ltsz. R 30563)

\section{THE COMPARISON OF THE ROYAL JOSEPH'S POLYTECHNIC'S AND THE HIGHER ARCHITECTURAL INDUSTRIAL SCHOO'S SUMMER SURVEYS}

The most important common point of the polytechnic's and the industrial school's holiday surveys is the connection to the institutional system of the cultural heritage management. Almost all of the surveys supervised by Steindl and in many instances, led by Foerk - directly or indirectly - were ordered and partly financed by the National Committee of Monuments [15] (for example Muzsna, Berethalom, Prázsmár, Szászbogács). Imre Steindl, thrilled by the success of the survey of Prázsmár in the previous year, at the meeting of the committe on 26 July 1875, asked 3300 florins for himself and his eight students to take an excursion to the mining towns in Upper Hungary. [16] In 1911, Ernő Foerk did likewise: he asked for a 1200 crown support to carry out a monumental survey of Medgyes and its surroundings with his ten third year disciples. [17]

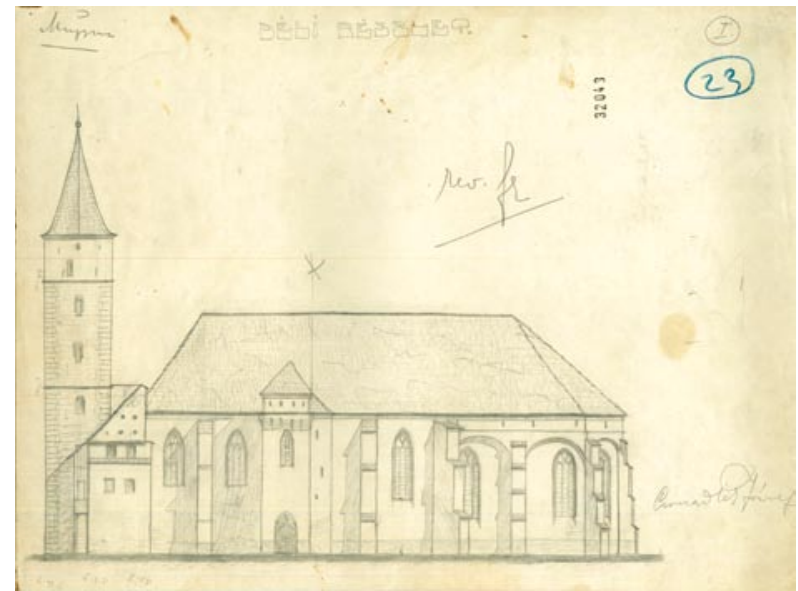

Picture 3. József, Csonzadlák: Muzsna, evangelical fortified church. South facade.

(Hungarian Royal Public Higher Architectural Industrial School, 1911. MMA, MÉM-MDK, Tervtár, ltsz. R 32043) 
This is how the survey of the evangelical fortified church in Muzsna as the first holiday took place in the same year. It is important to note that Foerk would have been a member of the National Committee of Monuments for a half year now, [18] so at the meetings of the Committe he was able to lobby for the financing of these surveys at the same level as Steindl had been able to do.

As another common point, it should be mentioned that, similarly to the publication of brochures which contain stone prints made in the Wiener Bauhütte's survey paths with the same title as the self-formation circle, [19] Steindl's first student surveys were also published in the form of a volume of twenty-one plates, the Hungarian Monuments I. [20] in 1878. The material of the holiday surveys carried out by the industrial school for about three decades from 1911 was published in a total of twelve volumes between 1912 and 1942, [21] and these publications are also regularly reported on various specialist journals (Archeological Announcer, Journal of Hungarian Engineers' and Architects' Association, Building Industry-Building Art etc.). „All of these buildings are shown in their original entirety, with their distinctive details, and even with a particular representation of some of their fixtures. As much as the choice of truly typical buildings is correct, the drawing's elaboration is so careful and meaningful too. Professor Foerk has also proved his excellent pedagogical capability this time!" [22] - wrote László Éber in connection with the volume presenting the Transylvanian churches in 1912.

It should be noted, in the meantime, that the differences between the two teachers are also reflected in the sources. At the committee's meeting on 13 June 1876, Steindl urged the financial support of the continuation of the monument-survey in Upper Hungary. He asked to pay 120 florins for his assistant, 105 florins for five of his more advanced students, while 75 florins for five of his less advanced students. [23] In his latter gesture there is a kind of performance orientation but Foerk did not use this kind of differentiation for the survey in Muzsna. He asked for a 5 crown daily allowance for all ten students, and he did not yet employ an assistant. [24] Participants of the visit came from his third-year students as opposed to surveys of the polytechnic in which usually four- and five-year students, ie. gradutes participated.

Another major difference is that during the first surveys of the polytechnic some students of the Hungarian Royal State Drawing and Drawing Teacher School (János Linde or Jenő Wallachy) also participated. The latter's monumental and architectural interest is evidenced by the fact that he exhibited his drawing depicting The main wall of the town hall in Luzern in the exhibition organized by his own educational institution in 1874. [25] The students of the drawing school mostly documented the altars, the fabrics and the goldsmith's works of the surveyed church so drawing the plans needed a different kind of drawing skills. By contrast, students from other institutions did not participate in the industrial school's holiday surveys. Thus, this documentation material provides a more uniform picture and it can rightly be assumed that the paths organized by Foerk provided the builder-students with a more complex experience in the field of monument survey. Jenő Gyárfás was the student of the drawing school who had participated in the course of students surveys and then as a painter he received the greatest appreciation among them because with his painting entitled Call to Tetime he won the Grand Prize of the Fine Arts Association in 1881, [26] as well as at the National Exhibition in 1885 his documentation drawings which were made during the Steindl-led surveys were also exhibited. [27] Let's mention here that one of the students of the industrial school, Károly Gráf, also participated at the Spring Exhibition of the Budapest Kunsthalle in 1913 with his watercolor entitled by The gothic church in Berethalom which made during the holiday survey in the previous year. [28] 


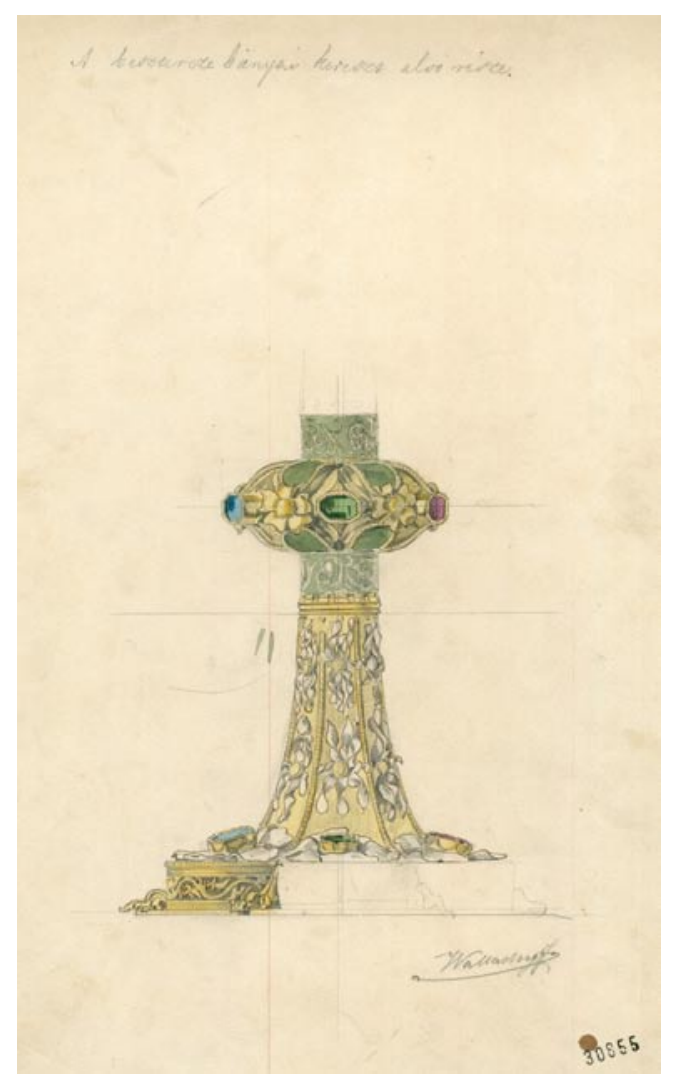

Picture 4. Jenő, Wallachy: Besztercebánya, roman catholic parish church. Gothic altar cross. (Joseph's Polytechnic-State Drawing and Drawing Teacher School, 1875. MMA, MÉM-MDK, Tervtár, ltsz. R 30855)

Of course, the holiday surveys of the industrial school were primarily funded by the Ministry of Commerce whose first assignment tended to the documentation of the churches in Szászkézd, Szászfehéregyháza, Nagykapus and Riomfalva. True, the drawings ordered by the ministry - after publication of their reproduction - were also included in the National Committee of Monuments' storage plan. The relationship with the office, partly communicated and maintained by Foerk's character, had a significant influence on the direction and subject of the holiday survey paths, as obviously they were arranged for such buildings which were not taken up until then. No wonder because there were only a very small number of architects at the beginning of the twentieth century in the committee's professional apparatuses. The survey work carried out by the students came at the right time. In addition, this lack of complementarity was complemented by the practical experience gained by the students.

The hegemony of the National Committee of Monuments as principal and the resulting selection logic prevailed primarily in the case of the polytechnic's student surveys. Here is a single example to support this. In his answer to Steindl's admission during the abovementioned commission meeting of 1876, the rapporteur of the committee, Imre Henszlmann stated that „Only one of the Steindl teacher's dual aims is closely related to our committee; the Minister of Honour should therefore be asked to cover the expenses of the students of the polytechnic and the sample education students half of the cost of these institutes." [29] And that was Henszlmann who, two years later, wrote in a record to Ágoston Trefort, Minister of Religion and Public Education that the „Hungarian Temporary Committee of Monuments 
has not yet drawings about the Romanesque styled church of Ják which is a great pearl of our Hungarian monuments [...] Imre Steindl, a teacher and a member of the commission should be entrusted with the survey and drawing of the church and for whom would still be a teacher assistant and five graduate students. [30]

Nevertheless, it seems to be that for some reason Steindl and Foerk may have managed to gradually expand this seemingly limited margin of maneuver and, to some extent, shape the direction of the surveys. On 20 May 1883, the former proposed to the National Committee of Monuments a survey of certain monuments of Spiš. Two days later, the committee at its meeting noted that ,it has got survey drawings of Spiš and Abaúj counties' monuments so it would be more useful to make the excursion elsewhere, namely to the region of Besztercze." [31] However, Steindl promised to make more accurate drawings than the existing ones and to draw the attention of his students to the surveyed monuments that had not surveyed until then. Thus, he got his original idea through the committee and organized the departure of 1883 in Lőcse, Késmárk and Szepeshely.

As we have seen, like his former role model Foerk also had a full say of where and what purpose to organize survey paths because in 1911 he himself proposed the survey of the Saxon fortified churches in Transylvania, ie of a monument-group which in several cases was at risk of total destruction at that time and for which less attention was paid to the cultural heritage management. It is illustrative from this point of view Gyula Forster's letter which was written to Ernö Foerk on 30 April 1916 and in which he states that in the future a greater emphasis will be placed on the discovery and preservation in addition to the monuments ,maintained by the state" to the other types of the monuments for example which have local significance. [32] Perhaps it is not by chance that Foerk devoted the sixth holiday survey to the mapping of Turkish monuments in Hungary the next year and the seventh to the architecture of the Hungarian village. In addition, the master published the scientific results of their departures to research the Turkish buildings in the form of an independent volume; [33] as well giving lecture entitled by The Turkish large mosques and turbes in Hungary as the sixth part of the series of lectures launched by the National Committe of Monuments in the autumn of 1925. [34]

With regard to how the personal ideas of Steindl and Foerk as an architect and a teacher shaped the holiday surveys two other important factors should be highlighted.

On the one hand, it is an inescapable fact from the point of view of science history that, although to a certain extent the 1910s surveys supervised by the Schmidt-schüler Foerk were influenced by the historicizing attitude from the previous century, [35] the departures headed by Steindl nevertheless did not only document medieval monuments. It is true that allround documentations have not been made about complete modern buildings, however laterenaissance and Baroque details of some medieval churches such as the stallum of the castle church in Kremnica, [36] a Roccoco gold plated copper chalice from the „Slovak church” in Selmecbánya, [37] or the Paradise Fence in the cathedral of Gyulafehérvár [38] were drawn. The Foerk-led surveys of the industrial school went even further in this area since in 1913 they were extended to the Rococco style Máriássy Castle of Márkusfalva and from 1915 onward to the Baroque and classicist late Baroque buildings of Budapest. In many cases these drawings are extremely important somewhat unique visual sources of monuments that have since been destroyed or have been radically rebuilt. An example of this is Lipót Göb, baker's house with its pigtail facade that once stood under 25 Margaret Boulevard, built about 1800 and demolished in 1942; the Three Rabbits Barrack under 69 Main Street, where today the headquarters of the Constitutional Protection Office is located; furthermore the old town tower (,Truncated Tower") in Dés which was a part of a Romanesque church became a ruin to the 18th century and was blown up by the Romanian authorities on 8 November 1938. [39] 


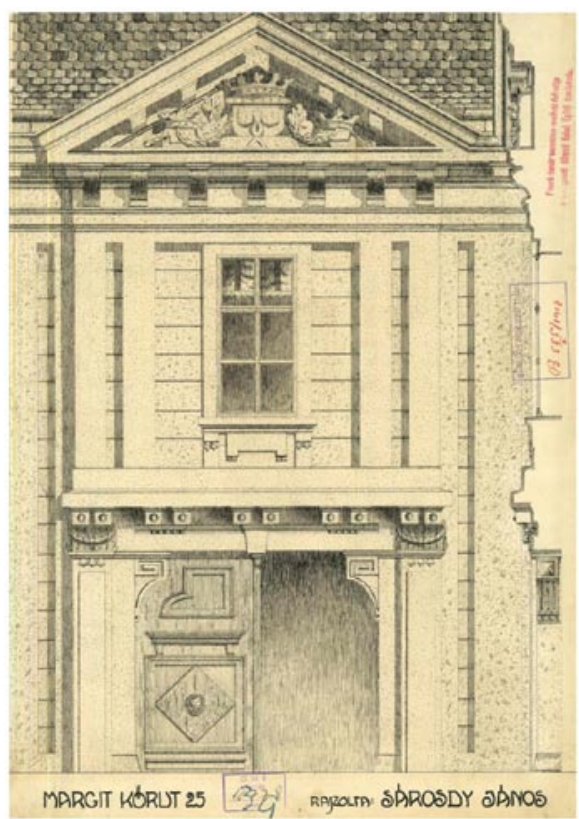

Picture 5. János, Sárosdy: Budapest, 25 Margaret Boulevard. The main facade.

(Hungarian Royal Public Higher Architectural Industrial Scool

1915. MMA, MÉM-MDK, Tervtár, ltsz. R 10778)

However another factor is connected to the supervising teacher's personal influence. In many cases it can detected that Steindl - based on the recordings - almost immediately made a puristoriented restoration plan about the church surveyed by his students. His drawings remained from 1876 referring to the Franciscan lower town church in Szeged, [40] and from 1878 to the former Benedictine abbey church in Ják. [41] The largest but unfinished reconstruction plan based on student surveys was made in 1898 on the cathedral of Gyulafehérvár: among other things it would have covered the western towers with a Gothic helmet and a construction for a four-tier tower.

A similar phenomenon can also be seen in relation to the industrial school's departures. In 1912 Foerk assessed the Lutheran fortified church in Berethalom with his students and in the same year he was commissioned by the local church to partially restore the building. Then due to lack of resources the work became stuck for two years but in 1914, when the parish hoped to receive the National Committee of Monuments' financial support, with the resumption Foerk was assigned again. [43] The situation was reversed in the case of the Máriássy Castle in Márkusfalva as well as the Reformed church in Dés whose vault reconstruction was discussed by the commission in 1912, [44] until on 22 February 1913 it asked Foerk again to carry out the necessary preparatory works. [45] This is why the teacher organized the next holiday survey in Dés that summer. His reconstruction plans of 1914 were drawn on the light prints which where made by his pupils the previous year.

The methods used in the polytechnic's and in the industrial school's surveys are essentially the same. The on-the-spot manuals are sketches usually made by pencil on larger sketchbook's - later turn out - pages. The cleared survey plans were recorded on paper then on tracing-paper initially in pen and later in black ink. In connection with the two phases of the work it should be mentioned that at the National Committee of Monuments' regular meeting on 22 February 1913 Foerk pushed for some extra renumeration for his students because the submitted drawings - evidently - were not elaborated during the recording but afterwards. [46] 


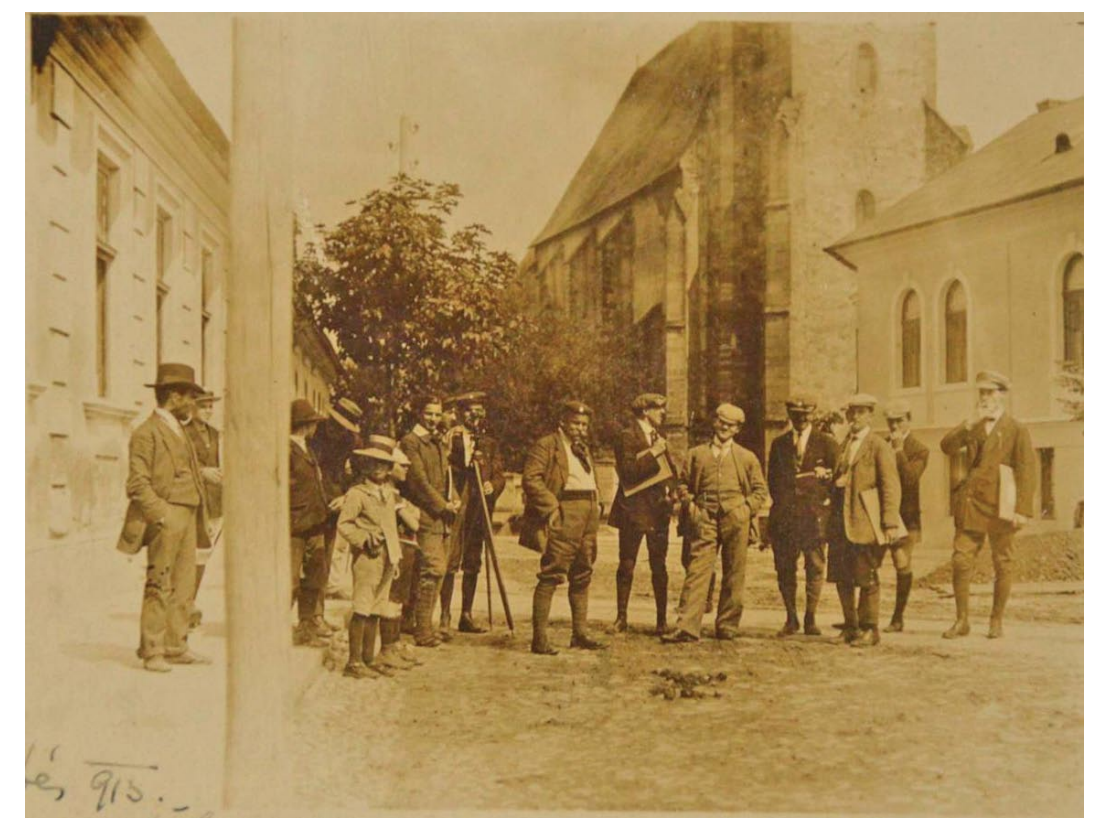

Picture 6. Henrik, Stiaszny: Group portrait in front of the calvinist church in Dés.

(Hungarian Royal Public Higher Architectural Industrial Scool, 1913. MMA, MÉM-MDK, Magyar Építészeti Múzeum)

Moreover in his address pleading the survey of the monuments in Medgyes he explains that a building can only be put up shortly after being shot accurately and reliaby, , and only by the one who took it". [47] Through coupling of the manuals and the cleared drawings, as well as examining the signatures of the papers it can be stated that - although there has certainly been a significant progress in the matter compared to the polytechnic's material [48] - the directive set by Foerk has not been fully implemented in about half of the cases.

The ground-plans, sections and facades, each with dimensions and sometimes with a detailed drawing, are usually on separate sheets. Obtaining the details in many cases is more realistic, more accurate and more elaborate on the survey plans of the industrial school. Their place in science history can be most expressively designated by the development observed in the documentation of floral ornaments. We have to point out that photographic documents have been made on the assessed buildings from the very first departure. This is evidenced by the album of 1911 showing the photos of the fortified church in Muzsna, [49] as well as Henrik Stiaszny's records of 1913 documented the Reformated church in Dés. [50] Furthermore, they have prepared for the on-site research of the building by collecting written resources. We know an attachment to the mentioned record of Medgyes, [51] in which the most important historical data (the earthquake, the fire, the dates of renovations) of the church of Muzsna are written in Foerk's handwriting. A similar case can be seen in connection with the student survey conducted by Steindl in the castle of Árva in 1896 which was already supervised by Károly Csányi. On the cover of Miklós Kubinyi's book entitled The castle of Arva which is preserved in the library of the Museum of Finer Arts in Budapest [52] the words „Károly Csányi 1894” can be read as crossed out. 


\section{ABOUT THE STUDENTS}

Finally, let's say a few words about the later activity of students who participated in the holiday surveys. The list of Steindl's students - with very few exceptions - seems to reinforce the thesis that in Hungary the most serious architectural orders until the turn of the $19^{\text {th }}-20^{\text {th }}$ century were gained by foreign-educated architects. [53] To name just one example to illustrate this: from among the former president and secretary of the Association of Polytechnic's Architect Students, [54] ie. Géza Trozonyi, after about a decade, and Emil Koderle right after receiving his degree left their architectural career.The same trend applies to builder and architect builder students who worked in the Foerk-led surveys. Their names appear at various points in the contemporary press, for example in the criminal box. In 1920 Jószef Csonzadlák due to counterfeiting received a two year prison sentence, [55] and six years later his forged degree was also discovered. [56] (While in 1911 he took advantage of his same capacity during survey of the fortified church in Muzsna.) Among the participants of the holiday surveys, the most important oeuvre was to be found by József Stippek. Some survey drawings of his legacy, which are composed of hundred items and also preserved in the Documentation Center of Cultural Heritage Management, [57] are the imprints of the drawing skill and the perception learned in the Foerk-school. Stippek's collection was based partly on his family inheritance, partly on forty-fifty wood statues from the $18^{\text {th }}-19^{\text {th }}$ century collected by him, and after his death in 1963 it got into the Hungarian National Museum. [58]

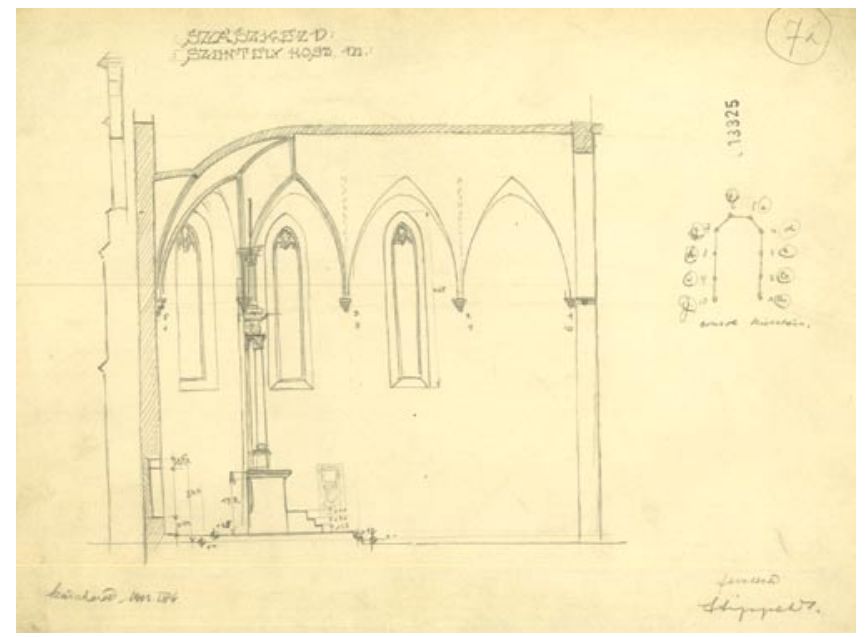

Picture 7. J ózsef, Stippek: Szászkézd, evangelical fortified church.

The longitudinal section of the chancel. (Hungarian Royal Public Higher Architectural Industrial Scool, 1912. MMA, MÉM-MDK, Tervtár, ltsz. R 13325)

To highlight another student. Károly Foerk's signature can be read on many onsite manuals. He is Ernő Foerk's older son whom the master wrote in his journal entry on 31 December 1911 as follows: „Károly seems to bend to architecture: in Muzsna and in Krasznabéltek he was with us; and in Dobóruszka he assessed the churches to be enlarged with me." [59] Károly Foerk was later a student of the Hungarian Royal Public Higher Architectural Industrial School. His name is included in the list of students who participated in the holiday survey in the summer of 1913 which targeted the Reformated church in Dés. [60] Shortly thereafter, he was led to the German front of the First World War where on 21 October 1917 „he died a heroic death by an enemy fragment". [61] 


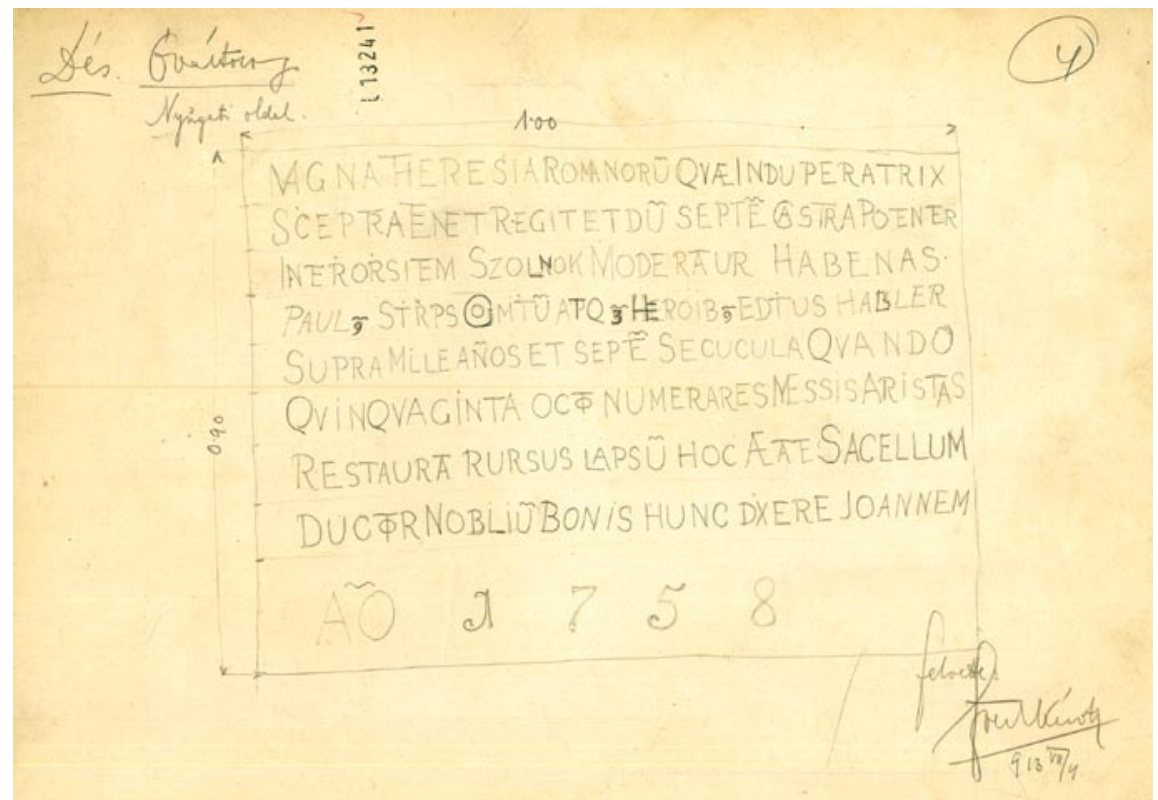

Picture 8. Károly, Foerk: Dés, „, Truncated Tower”. Inscription board (1758) on the west facade. (Hungarian Royal Public Higher Architectural Industrial Scool, 1913. MMA, MÉM-MDK, Tervtár, ltsz. R 13241)

\section{SUMMARY}

In conclusion we would like to emphasize once again that the holiday surveys of the Hungarian Royal Public Higher Architectural Industrial Scool continued the special features of the polytechnic's student surveys which were rooted in the Wiener Bauhütte's methodology. With the help of Ernö Foerk this tradition was almost uninterrupted in the Hungarian architect's education until the middle of the twentieth century.

The question is, on the basis of resources, where to precisely locate the science history of Hungarian art. More concretely: can the continuous practice of holiday surveys be interpreted as the influence of Viennese architecture influenced on Hungarian art in the late historicism of the early twentieth century?

On this issue, some of the appeals were formulated in some places. According to one thesis of the debate „From the architectural point of view Budapest emancipated from Wien after the Compromise was also strongly associated with the Emperor's town.", [62] while the opposite stance states that „Budapest seemed to have lost sight of Wien as a cultural center at the time. [...] It is characteristic for example that the greatest Hungarian poet of the century, Endre Ady and the greatest composer, Béla Bartók has not got $<<$ Viennese era $>>$." [63]

In our opinion both viewpoints have their own truths independently of each other. In connection with our subject we would solve this apparent conflict in such a way that in the case of student surveys it is not so much about Wien but rather about a powerful influence of Friedrich von Schmidt's model. Which again emphasizes the mediating role of the Cultural Heritage Management's system in this chapter of the history of architecture in Hungary. 


\section{REFERENCES}

[1] Pusztai L., Foerk Ernő mủemlékvédelmi munkásságáról. In: Foerk Ernő (1868-1934) épitész emlékkiállitása. Exhibition catalog. Szerk. Pusztai L., Hadik A. Budapest, OMF - Magyar Építészeti Múzeum, 1984, pp. $14-17$.

[2] HaDik A., Foerk Ernőről és a Magyar Építészeti Múzeumban lévő dokumentumanyagáról, Lapis Angularis, Volume 2 (1998), 17-18.

[3] A Magyar Királyi Állami Felső Épitö Ipariskola szünidei felvételei 1912-1942. Írta: FoerK E. Előszót írta: DéRY A. Budapest: Terc Kiadó, 2002, pp. 1-3.

[4] Fleischer Gy., Magyarok a bécsi Képzömüvészeti Akadémián, Budapest: Magyar Tudományos Akadémia, 1935, pp. 42. Foerk was Schmidt's pupil from 1889 until July 1891. Between October 1891 and July 1892 he was a member of Victor Luntz's masterclass.

[5] J. Sisa, Steindl, Schulek und Schulcz - Drei Ungarische Schüler des Wiener Dombaumeisters Friedrich von Schmidt, Mitteilungen der Gesellschaft für Vergleichende Kunstforschung in Wien, Volume 37 (1985), No 3, 1.

[6] Sisa J., Magyar építészek külföldi tanulmányai a 19. század második felében, Müvészettörténeti Értesitő, Volume 45 (1996), No 1-2, 174.

[7] SisA J.: Steindl Imre, a müemlék-restaurátor. In: Romantikus kastély. Tanulmányok Komárik Dénes tiszteletére. Szerk.

VADAS F. Budapest: Hily-Ybl Alapítvány, 2004. [hereinafter: Sisa 2004a] pp. 300.

[8] BME Levéltár 9.) Építőmérnöki Kar Dékáni Hivatala 1876-1960, b.) A Mérnök és Építészmérnöki Kar közös kari tanácsülési jegyzőkönyvei 1876-1950, 1. kötet: 1876-1904, 1893/94.

[9] Foerk Ernő munkái naplójából kiírva. MMA, MÉM-MDK, Magyar Építészeti Múzeum, without inventory number [w. i. n.]

[10] Foerк E., Steindl Imre emlékezete, A Magyar Mérnök- és Épitész-Egylet Közlönye, Volume 61 (1927), 305.

[11] Provides a short biographical review: Magyar Életrajzi Lexikon, II. (L-Z) Főszerk. KenyerEs Á. Budapest: Akadémiai Kiadó, 1982. pp. 596.

[12] A Magyar Királyi Állami Felsö Építö Ipariskola szünidei felvételei 2002. already quoted [a. q.] pp. 2-3.

[13] Épitö Ipar-Épitö Müvészet, Volume 55 (1931), 89: in 1894 Schodits obtained his degree in architecture at the Joseph's Polytechnic (diploma number: 975). Therefore, in 1896 he could certainly have attended as an assistant in the survey in Árva. [14] Manuals which were made during the survey(s) in Árva and signed by Schodits: MMA, MÉM-MDK, Tervtár, inventorynumber [i. n.] R 30543, R 30546, R 30552, R 30557, R 30559, R 30563, R 30568-30569, R 30573-30575, R 30585, R 30597-30598, R 30609-30610, R 30614, R 30634, R 30637, R 30646, R 30660, R 30666.

[15] It should be noted that Wiener Bauhütte also operated with central funding, with the support of the Austrian Government, which see: SisA J.: A Schmidt-iskola Budapesten. In: Az áttörés kora. Bécs és Budapest a historizmus és az avantgárd között (1873-1920). Exhibition catalog. Szerk. F. Dózsa K. Budapest, Budapesti Történeti Múzeum, 2004. [hereinafter: SISA 2004b] pp. 139.

[16] MMA, MÉM-MDK, Tudományos Irattár, MOB iratok, 1875/3.

[17] MMA, MÉM-MDK, Tudományos Irattár, Lymbus, Foerk Ernő-hagyaték, i. n. K 2016/5/4. Published: HaDIK 1998. a. q. $20-21$.

[18] MMA, MÉM-MDK, Tudományos Irattár, Lymbus, Foerk Ernő-hagyaték, i. n. K 2015/1.

[19] Ковомрау Gy.: Steindl Imre és Schulek Frigyes alakja a müegyetemi hagyományban. In: Steindl Imre (1839-1902) épitész, müegyetemi tanár emlékezete. Conference publication. Szerk. Horváth A. Budapest: Budapesti Műszaki Egyetem, 1989. pp. 13.

[20] Magyarországi müemlékek, I. Kiadja: STEINDL I. Budapest, 1878.

[21] Collected and reedited see: A Magyar Királyi Állami Felső Építő Ipariskola szünidei felvételei 2002. a. q.

[22] ÉBER L., A Budapesti Magyar Királyi Állami Felső Építő-Ipariskola 1912 évi szünidei felvételei, ArcheológiaiÉrtesitö, Volume 33 (1913), 184.

[23] MMA, MÉM-MDK, Tudományos Irattár, MOB iratok, 1876/53.

[24] This was probably changed later because Foerk named Gyula Schmidt D. as his ,,co-teacher” in connection with the survey of the Roman Catholic church in Felka, which see: A Magyar Királyi Állami Felsö Épitö Ipariskola szünidei felvételei 2002. a. q. II/3.

[25] A Mintarajztanodától a Képzőmüvészeti Főiskoláig. Szerk. BLaskónÉ MaJKó K., SzőKe A. Budapest: Magyar Képzőművészeti Egyetem, 2002, pp. 80. Kat. 5. 
[26] Bernáth M.: Gyárfás Jenő (1857-1925.). In: Magyar müvészet 1890-1919, I. Szerk. NÉMETh L. Budapest: Akadémiai Kiadó, 1981, pp. 204; Almásı T., Egy festmény genezise és utóélete. Gyárfás Jenő: Tetemrehívás, Arrabona, Volume 37 (1999), 323-336.

[27] MMA, MÉM-MDK, Tudományos Irattár, MOB iratok, 1885/38: „Jenő, Gyárfás: „Slovak church” in Selmec ; Jenő, Gyárfás: The sacrarium of church in Zólyom; Jenő, Gyárfás: The chalice of church in Zólyom.

[28] Szendrei J., Szentiványi Gy., Magyar képzömüvészek lexikona, I, Budapest: Közoktatásügyi Minisztérium, 1915, pp. 594.

[29] MMA, MÉM-MDK, Tudományos Irattár, MOB iratok, 1876/53.

[30] MMA, MÉM-MDK, Tudományos Irattár, MOB iratok, 1878/55.

[31] MMA, MÉM-MDK, Tudományos Irattár, MOB iratok, 1883/36.

[32] MMA, MÉM-MDK, Tudományos Irattár, Lymbus, Foerk Ernő-hagyaték, i. n. K 2015/18.

[33] Foerк E., A Török emlékek Magyarországon, Budapest: Corvin Nyomda, 1918. (Reedited: Foerk E., Török emlékek Magyarországban, Budapest: TIKA Budapesti Koord. Irodája, 2016.)

[34] MMA, MÉM-MDK, Tudományos Irattár, Lymbus, Foerk Ernő-hagyaték, i. n. K 2015/21.

[35] At the same time, Foerk made the critique of the purist approach even at the time of the beginning of holiday surveys. In 1912, during his trip to Italy, in a note dated on 2 May he wrote about the cathedral of Orvieto: „The church is now under restoration and has taken away its later movable treasures from it and it does not seem to want to be reinstated because they arealready int he Museo civico. In short, they are purified, pulled on a shoehorn like a lot of historical memories just to be stylistic.”; see: Foerk E., Olasz levelek, Budapest: Corvin Nyomda, 1912. pp. 5. And adds itt o your next day's note: „For me it was so artistic work the Pantheon or the Colosseum, the S.-Apollinare, the S.-Ambrogio, and the cathedral of Milan or Orvieto, as the Saint Peter Church or Il Gesú in Rome.”; see: Foerk 1912. a. q. 7.

[36] Unknown author. Körmöcbánya, r. k. plébániatemplom. A stallum (1620) nézetrajza. Pencil drawing Körmöcbánya, 1875. MMA, MÉM-MDK, Tervtár, i. n. R 31665.

[37] Platzer Antal: Selmecbánya, r. k. templom. Rokokó aranyozott réz kehely nézetrajza és részletrajza. Ceruzarajz. Selmecbánya, 1875. MMA, MÉM-MDK, Tervtár, i. n. R 31803. See: A ,szentek fuvarosa”. Divald Kornél felsö-magyarországi

topográfiája és fényképei 1909-1919. Szerk. Bardoly I., Cs. Plank I. Budapest: Országos Műemlékvédelmi Hivatal, 1999, pp. 156: „14. Kehely, aranyozott réz, XVIII. század.”

[38] Csányi Károly: Gyulafehérvár, székesegyház. Az ún. Paradicsom-kerités pillérszobrainak (Ribiczei Katalin és Csiszár Miklós címereit tartó puttófigurák) nézetrajzai. Pencil drawing. Gyulafehérvár, 1896. MMA, MÉM-MDK,

Tervtár, i. n. K 4605.

[39] Entz G., A dési református templom, Kolozsvár: Erdélyi Múzeum-Egyesület, 1942, pp. 15; LÉstyán F., Megszentelt kövek. A középkori erdélyi püspökség templomai, II, Kolozsvár: Gloria Kiadó, 1996, pp. 434-435.

[40] Reconstruction plans drawn up by Steindl about the Franciscan lower town church in Szeged in 1876: MMA, MÉM MDK, Tervtár, i. n. R 6515-6525. See: LuKÁcs Zs.: Előzetes beszámoló a Szeged-alsóvárosi ferences kolostor kutatásáról. In: Koldulórendi épitészet a középkori Magyarországon. Szerk. HaRIs A. Budapest: Országos Müemlékvédelmi Hivatal, 1994 , pp. 451. [41] Reconstruction plans drawn up by Steindl about the former Benedictine abbey church on Ják in 1878: MMA, MÉM MDK, Tervtár, i. n. R 14325, R 14415, R 14424, R 14510.

[42] Reconstruction plans drawn up by Steindl about the cathedral of Gyulafehérvár in 1898: MMA, MÉM-MDK, Tervtár, i.n. K 2195, K 2196, K 2199, K 2201, K 2203, K 2206. Which see: SisA 2004a a. q. 308.

[43] MMA, MÉM-MDK, Tudományos Irattár, MOB iratok, 1914/309.

[44] MMA, MÉM-MDK, Tudományos Irattár, MOB iratok, 1913/16.

[45] MMA, MÉM-MDK, Tudományos Irattár, MOB iratok, 1913/852.

[46] MMA, MÉM-MDK, Tudományos Irattár, MOB iratok, 1913/143.

[47] MMA, MÉM-MDK, Tudományos Irattár, Lymbus, Foerk Ernö-hagyaték, i. n. K 2016/5/4. Published: HADIK 1998. a. q. 20 -21. [48] See: A budapesti m. kir. állami felső építőipariskola szünidei felvételei az 1912-15. évben, A Magyar Mérnök- és Épitész Egylet Közlönye, Volume 51 (1917), 96.

[49] MMA, MÉM-MDK, Magyar Építészeti Múzeum, i. n. 70.611-70.628.

[50] MMA, MÉM-MDK, Magyar Építészeti Múzeum, i. n. 70.466, 70.507.

[51] MMA, MÉM-MDK, Tudományos Irattár, Lymbus, Foerk Ernő-hagyaték, i. n. K 2016/5/4. 
[52] Kubinyı M., Árva vára: történelmi tanulmány, Budapest: Franklin, 1890. In: Szépmüvészeti Múzeum, Könyvtár, i. n. 7508.

[53] Sisa 1996. a. q. 169.

[54] Vasárnapi Ússág, Volume 25 (1878), 12.

[55] Világ, Volume 11 (1920), No 90, 5.

[56] Magyarország, Volume 35 (1928), No 220, 1-2.

[57] Stippek's monument monitoring activity started shortly after the completion of the Hungarian Royal Public Higher Architectural Industrial School. For the first time in October 1923, he first offered the National Committee of Monuments for the survey of certain buildings, suchas the churches of Szentsimony, Hangony, Uraj, Sikátor and Arló; which see:

MMA, MÉM-MDK, Tudományos Irattár, MOB iratok, 1923/400.

[58] m. d., Stippekék Múzeuma, Népszava, Volume 91 (1963), No 287, 4; Kunszery Gy., Szent Flóriántól-Sztahanovig, Új Ember, Volume 21 (1965), No 43, 2.

[59] Foerk Ernő munkái naplójából kiírva. MMA, MÉM-MDK, Magyar Építészeti Múzeum, w. i. n.

[60] MMA, MÉM-MDK, Tudományos Irattár, Lymbus, Foerk Ernő-hagyaték, i. n. K 2016/2/2. In addition, in the Foerk legacy of the Hungarian Museum of Architecture there is a black and white group picture with no inventory number in which the figure of Károly Foerk was marked with the subtitle „Karoly”.

[61] Foerk Ernő munkái naplójából kiírva. MMA, MÉM-MDK, Magyar Építészeti Múzeum, w. i. n.

[62] SisA 2004b a. q. 137.

[63] Gergely A.: Bécs és Budapest az Osztrák-Magyar Monarchiában. In: Az áttörés kora 2004. a. q. pp. 117. 